\title{
BWMK1, a Novel MAP Kinase Induced by Fungal Infection and Mechanical Wounding in Rice
}

\author{
Chaozu He, Steven Haw Tien Fong, Daichang Yang, and Guo-Liang Wang \\ Institute of Molecular Agrobiology, The National University of Singapore, 1 Research Link, Singapore \\ 117604 \\ Accepted 25 August 1999.
}

\begin{abstract}
The activation of the mitogen-activated protein (MAP) kinases by different environmental stresses has been previously observed in several dicot plant species. Here, we report the isolation of a novel MAP kinase in rice that is induced during infection by the blast fungus Magnaporthe grisea or upon mechanical wounding. The gene is designated as $B W M K 1$ for blast- and wound-induced $\underline{M A P}$ kinase. The cDNA of $B W M K 1$ was isolated from rice leaves challenged by the blast pathogen. Transcripts of the corresponding gene accumulated in rice leaves $4 \mathrm{~h}$ after blast inoculation and $30 \mathrm{~min}$ after mechanical wounding. This gene encodes a 506 amino acid protein that contains a new dual-phosphorylation activation motif TDY and about 150 unique amino acids on its $C$ terminus. In-gel kinase activity and immunoprecipitation assays confirmed that BWMK1 is a functional MAP kinase. These results show that BWMK1 is a new member of the plant MAP kinase family and may mediate both defense and wound signaling in rice.
\end{abstract}

Additional keywords: Oryza sativa, rice blast.

Living cells continually adapt to changes in environmental conditions by modulating their gene expression. Protein phosphorylation appears to be the principal mechanism for rapid modulation of transcription factor activity in response to extracellular signals (Somssich 1997). One of the major pathways by which extracellular signals are transduced intracellularly is the mitogen-activated protein (MAP) kinase signaling cascade. The cascade is known to be conserved throughout eukaryotes and consists of a MAP kinase kinase kinase (MAPKKK), a MAP kinase kinase (MAPKK), and a MAP kinase (MAPK). The activation of a MAP kinase occurs through threonine/tyrosine phosphorylation that is catalyzed by the dual-specificity MAPKK, which in turn is activated through serine phosphorylation catalyzed by MAPKKK

Corresponding author: Guo-Liang Wang, The Institute of Molecular Agrobiology, The National University of Singapore, 1 Research Link, Singapore 117604; Telephone: (65) 872 7420; Fax: (65) 872 7007, Email: wanggl@ima.org.sg

Current address of Guo-Liang Wang: Department of Plant Pathology, The Ohio State University, Kottman Hall, 2021 Coffey Road, Columbus 43210-1087, U.S.A.; Telephone: 1-614-292-9280; Fax: 1-614-292-445.

Nucleotide and/or amino acid sequence data can be found at the GenBank data base as accession no. AF177392.
(Hunter 1995). These three interlinked protein kinases form the basic module of a MAP kinase pathway in which an extracellular stimulus or perturbation is perceived by a plasma membrane receptor and then transduced into the nucleus (Hirt 1997). Several MAP kinase pathways in yeast and mammalian cells have been fully elucidated and are implicated in a wide variety of physiological processes such as cell growth, differentiation, oncogenesis, and response to environmental stresses (Kyriakis and Avruch 1996). Among them, two groups of mammalian MAP kinases, SAPK/JNK and p38, have been found that are activated in response to various stress signals, including UV and ionizing radiation, pro-inflammatory cytokines, endotoxin, interleukin-1, and hyperosmolar and oxidative stress (Marshall 1994; Kyriakis and Avruch 1996). Transient activation of these MAP kinases leads to the induction of different defense responses and thereby allows cells to adapt to adverse environmental conditions.

Emerging evidence has shown that MAP kinases also play an important role in plant signal transduction, particularly in the response to stress conditions (Hirt 1997). Several stressinduced MAP kinases have been identified in plants that are responsive to cold, heat, wounding, drought, a fungal elicitor, and salicylic acid (SA) (Seo et al. 1995; Jonak et al. 1996; Bogre et al. 1997; Ligterink et al. 1997; Zhang and Klessig 1997; Zhang et al. 1998; Zhang and Klessig 1998a). Among them, two MAP kinase genes, i.e., ERMK and SIPK, were shown to be involved in the defense response to microbial pathogens. The $48-\mathrm{kDa}$ MAP kinase (ERMK) is rapidly activated upon high-affinity binding of a fungal elicitor to a plasma membrane receptor in parsley suspension cells and the activated ERMK is translocated into the nucleus, where it may be involved in the transcriptional activation of defense genes (Ligterink et al. 1997). The tobacco MAP kinase gene, SIPK, was reported to be activated by SA treatment, cell-wallderived carbohydrate elicitor, two purified elicitins from Phytophthora spp., bacterial harpin, tobacco mosaic virus (TMV), and the avirulence gene Avr9 product of Cladosporium fulvum in tobacco (Zhang and Klessig 1997; Zhang et al. 1998; Zhang and Klessig 1998a, 1998b, 1999; Romeis et al. 1999). These results suggest that MAP kinases may be an important component in the signal transduction pathway of plant defense mechanisms to pathogens, and that different defense signals may converge on the same MAP kinase pathway(s).

Another group of plant MAP kinases was induced by wounding caused by mechanical injury or pathogen/herbivore attack (Hirt 1997). With the use of sodium dodecyl sulfate 
(SDS)-polyacrylamide gels containing myelin basic protein (MBP), a 46-kDa protein kinase was found to be activated by leaf cutting in tobacco (Usami et al. 1995). The protein kinase activity was also detected in response to leaf wounding in a variety of species of monocotyledons and dicotyledons. The wound-induced MAP kinase, WIPK, in tobacco was identified by differential hybridization (Seo et al. 1995). Transcription of the WIPK gene accumulated 1 min after mechanical wounding. Overexpression of the gene in transgenic tobacco led to inactivation of the endogenous WIPK, resulting in the suppression of the wound response. Using specific antibodies, Bogre et al. (1997) showed that the alfalfa p44 MMK4 kinase was activated by wounding within $1 \mathrm{~min}$ but decreased to basal levels within $30 \mathrm{~min}$. It has been proposed that p44MMK4 acts independently of other wounding signals, such as abscisic acid, methyl jasmonic acid, and electrical activity, since none of these factors were able to activate the kinase in the absence of wounding.

Pathogen infection and wounding are two distinct signals to plants. MAP kinase convergence of these two pathways has been recently reported. For example, Zhang and Klessig (1998a) demonstrated that the tobacco MAP kinase, SIPK, was induced by mechanical wounding, suggesting that SIPK may facilitate signaling for diverse defense pathways. More interestingly, they found that the tobacco wound-induced MAP kinase WIPK was activated by TMV only in plants containing the disease-resistance gene $N$ (Zhang and Klessig 1998b). It was speculated that WIPK may be an important component upstream of SA in the signal transduction pathway(s) leading to local and systemic resistance to TMV since the induction of WIPK mRNA and protein occurred systematically and was independent of SA. Recently, Romeis et al. (1999) investigated the Avr9/Cf-9-dependent activation of protein kinases in transgenic tobacco expressing the $C f-9$ gene. It was found that WIPK and SIPK were activated rapidly within 2 to $5 \mathrm{~min}$ after $A v r 9$ elicitation in both tobacco cells and plants, demonstrating not only that signal pathways derived from different $\mathrm{R}$ genes share components but also that signaling is triggered by diverse biotic and abiotic stresses.

Rice blast is the most devastating disease of cultivated rice (Oryza sativa) and is caused by the filamentous fungus Magnaporthe grisea, which can also cause disease of many species of the grass (Poaceae) family (Ou 1985). Understanding the interaction between rice and $M$. grisea at the cellular and molecular level should provide us with insights for the effective control of the disease. It has been known that $M$. grisea executes a series of developmental and metabolic pathways from the time the spores land on the rice leaf surface to production of sporulating lesions (Howard and Valent 1996). Lytic enzymes and also the mechanical force of appressorium formed from germinated spores are necessary for the successful penetration of the fungus into rice epidermal cells (Howard and Valent 1996). Even though some pathogenesis-related genes have been identified during blast infection (Zhu and Lamb 1991), little is known about the host resistance mechanism during the initial infection stages (before penetration) of M. grisea. We report here the cloning and characterization of a novel MAP kinase gene from rice plants, designated as $B W M K 1$ (for blast- and wound- induced $\underline{M} A P$ kinase), since it was shown to be induced not only by the blast fungus but also by mechanical wounding. Our results suggest that BWMK1 might be a mediator of at least two extrinsic signals in rice, namely fungal infection and wounding.

\section{RESULTS}

\section{Isolation of a cDNA fragment induced in rice plants after blast inoculation.}

To isolate disease resistance gene homologs in rice, two primers, CF9-RT and CF9-Rev, were designed based on the DNA sequence of the tomato disease resistance gene $C f-9$ (N. Naqvi and H. Leung, IRRI, unpublished; see Materials and Methods for sequence details; Jones et al. 1994). mRNAs isolated from the plants of C101A51 (blast resistant) and CO39 (blast susceptible) (Mackill and Bonman 1992) at 0 and $8 \mathrm{~h}$ after inoculation with blast isolate 103 were used as a template in first-strand cDNA synthesis. When primers CF9-RT and CF9-Rev were used in a reverse transcriptase-polymerase chain reaction (RT-PCR), four strong bands were amplified only in the infected plants of both resistant and susceptible lines (data not shown). These cDNA fragments were then cloned into the pGEM-T vector. Four clones with different insert sizes $(350,450,700$, and $800 \mathrm{bp}$, respectively) were identified and sequenced. Data base searches with the BLAST program at the National Center for Biotechnology Information (NCBI) revealed that the 350-bp cDNA sequence was highly homologous to known MAP kinases whereas there were no hits for the other three sequences in the data bases. At the amino acid level, searches found $80 \%$ identity with a MAP kinase-like protein from Selaginella lepidophylla (accession no. U96716), 48\% identity with MAP kinase SIPK from tobacco (Zhang and Klessig 1997), and 45\% identity with human MAP kinase BMK1 (Lee et al. 1995; Kato et al. 1997). These results indicated that the cDNA fragment obtained from the infected rice leaves is part of the coding region of a MAP kinase gene that is responsive to blast fungus in rice.

The regions corresponding to the two primers used in the RT-PCR were searched for in the sequence of the 350-bp cDNA fragment. It was found that primer CF9-RT was used for both the forward and reverse primers to amplify the fragment. When it was used as the forward primer, 12 out $18 \mathrm{bp}$ of the primer were the same as those of the amplified cDNA sequence. As a reverse primer, it annealed to the reverse cDNA strand where 9 out of $18 \mathrm{bp}$ of the primer were the same as those of the amplified cDNA sequence (Fig. 1). The high level of primer sequence mismatch could be due to the relative low annealing temperature $\left(55^{\circ} \mathrm{C}\right)$ used in the RT-PCR.

\section{Isolation of $B W M K 1 \mathrm{cDNA}$ and genomic clones.}

Comparison with known MAP kinases showed that the 350bp cDNA fragment contained only the conserved catalytic domains I, II, III, and IV (Zhang and Klessig 1997). To clone a full-length cDNA clone of $B W M K 1$, a rice cDNA library was constructed with mRNAs isolated from infected plants of resistant isogenic line C101A51. The library (about $1 \times 10^{6}$ clones) was screened with the 350-bp fragment as a probe. Three positive clones (MC8, $1.7 \mathrm{~kb}$; MC11, $1.7 \mathrm{~kb}$; and $\mathrm{MC15}, 2.0 \mathrm{~kb}$ ) were identified and sequenced. All three clones contained a poly A tail. MC15 was the largest clone and carried an open reading frame of $1,427 \mathrm{bp}$. Sequence analysis indicated that MC15 was not a full-length cDNA 
clone since it lacks the conserved MAP kinase domain I and a translation initiation site.

To isolate the DNA fragment spanning the ATG initiation codon region of $B W M K 1$, a rice bacterial artificial chromosome (BAC) library of cultivar IR64 (Yang et al. 1997) was screened with the 350-bp cDNA fragment as the probe. Four positive BAC clones (3-O7, 17-H21, 43-H15, and 43-F5) were identified from the BAC library. Miniprep DNA of the four BAC clones was digested with three different restriction enzymes (EcoRI, EcoRV, and HindIII) to check whether they were overlapping clones in a chromosomal region. Based on restriction enzyme digestion and Southern hybridization patterns, it was found that these four clones were overlapping (data not shown). Thus, the BAC clone 3-O7 (about $100 \mathrm{~kb}$ ) was chosen for subcloning. When the clone was digested with restriction enzyme EcoRI, a 4.5-kb fragment was hybridized with the 350-bp cDNA fragment. This fragment was then ligated into pBluescript-SK vector (Stratagene, La Jolla, CA).

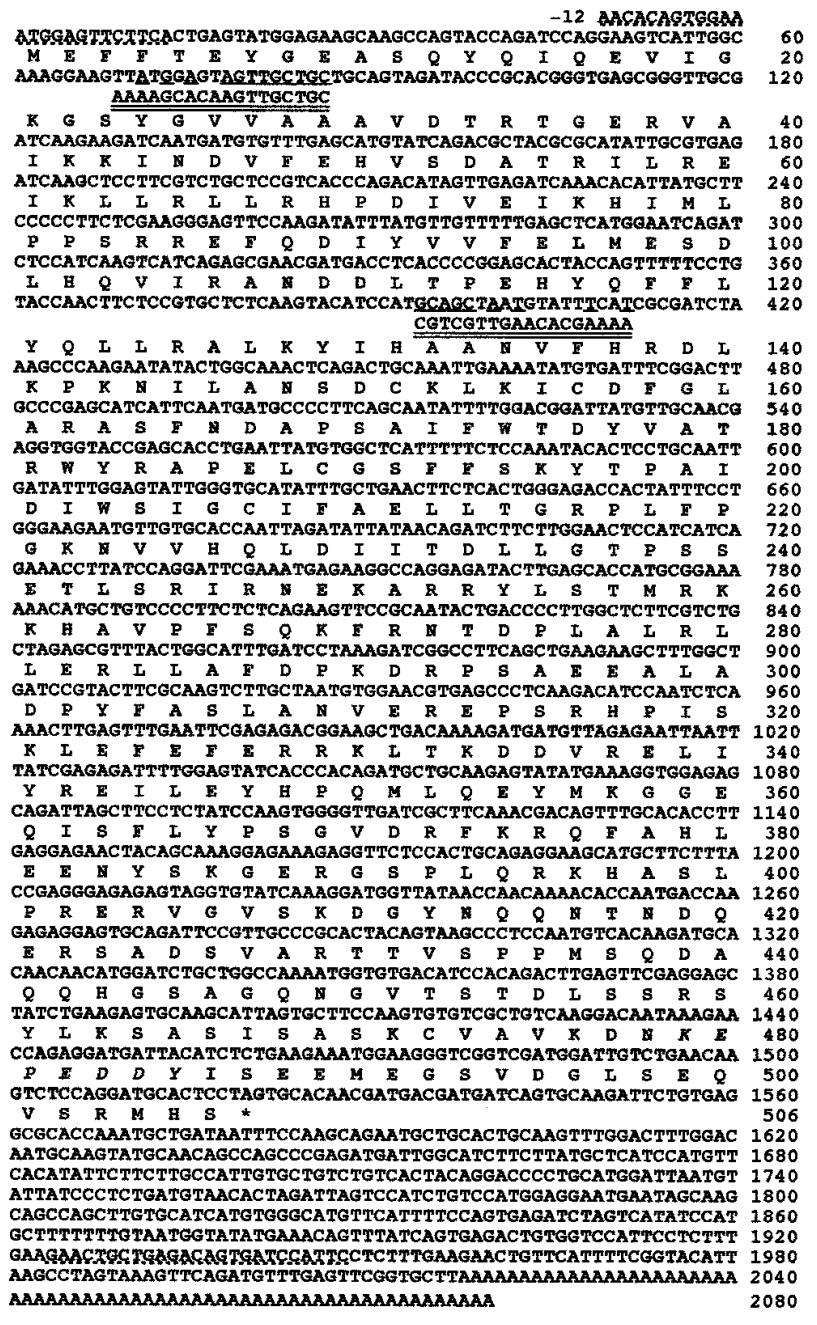

Fig. 1. Nucleotide and deduced amino acid sequences of the $B W M K 1$ gene (GenBank accession number AF177392). Sequence of primer CF9RT is double-underlined; primer nucleotides identical to DNA sequence are underlined. A putative tyrosine phosphorylation site is italicized (amino acids 479 to 485$)$. Primers BWMK1-F1 (-12 to 13) and BWMK1-R1 (1923-1948) are dot-underlined.
The recombinant clone was used for DNA sequencing. Sequence analysis revealed that the $4.5-\mathrm{kb}$ fragment contained the $5^{\prime}$ region of the gene including the putative promoter and a part of the coding region (about 400 bp after the ATG initiation codon).

\section{BWMK1 contains all 11 conserved catalytic domains of eukaryotic MAP kinase and unique structure in its $\mathbf{C}$ terminus.}

To isolate the full-length $B W M K 1$ cDNA from rice, two primers (BWMK1-F1 and BWMK1-R1) were designed. The forward primer BWMK1-F1 contains the sequence spanning the putative ATG initiation codon (Fig. 1) based on the genomic DNA sequence. The reverse primer BWMK1-R1 anneals to the sequence 402 to $426 \mathrm{bp}$ after the stop codon, based on the sequence of the cDNA clone MC15. With these two primers, a 2.0-kb RT-PCR product was obtained from the cDNA prepared from infected leaves of C101A51 (8 h after inoculation). The PCR product was cloned into the pGEM-T vector and sequenced. Upon comparison of the sequences of the cDNA clone MC15, the 4.5-kb genomic clone and the 2.0$\mathrm{kb}$ RT-PCR product, it was found that only $91 \mathrm{bp}$ after the ATG initiation codon were missing in the cDNA clone MC15. The nucleotide and deduced amino acid sequences of the $B W M K 1$ gene are shown in Figure 1.

$B W M K 1$ contains a 1,518 bp (506 amino acid) open reading frame that could code for a protein of molecular mass 57.9 $\mathrm{kDa}$, calculated with the computer software DNAStar (DNAStar, Madison, WI). The alignment of the deduced protein sequence with other MAP kinases indicated that BWMK1 was significantly homologous to the MAP kinases isolated from a variety of organisms (Fig. 2A). It contains all the 11 conserved amino acids and peptide motifs characteristic of 11 subdomains of protein kinases with serine/threonine specificity, which are present in all known MAP kinases from yeast, mammals, and plants (Hanks and Quinn 1991; Hirt 1997). Comparison of the amino acid sequence of BWMK1 with other cloned plant MAP kinases showed that their identities were in the range of 40 to $50 \%$. For instance, it shows $50 \%$ identity to the SA, wounding, elicitor-induced MAP kinase SIPK (Zhang and Klessig 1997; Zhang et al. 1998) from tobacco, $47 \%$ identity to the wound and tobacco mosaic virusinduced MAP kinase WIPK (Seo et al. 1995; Zhang and Klessig 1998b) from tobacco, and $49 \%$ identity to the fungal elicitor-responsive MAP kinase ERMK from parsley (Ligterink et al. 1997). However, the rice MAP kinase has a unique amino acid, aspartic acid (D), between the threonine $(\mathrm{T})$ and tyrosine $(\mathrm{Y})$ residues in the dual phosphorylation site located between subdomains VII and VIII of the kinase catalytic domain (Fig. 2A). The residue between threonine and tyrosine in all identified eukaryotic MAP kinases can be either Glu (E), Pro (P), or Gly (G).

Most eukaryotic MAP kinases are 38- to 55-kDa molecular mass proteins. The largest MAP kinase identified so far is the mammalian $B M K 1$ gene, which encodes a $80-\mathrm{kDa}$ protein and contains a large $\mathrm{C}$ terminus and a unique loop-12 sequence (Lee et al. 1995). In addition to the 11 conserved domains, BWMK1 has an extra domain containing about 150 amino acids in its $\mathrm{C}$ terminus. A data base search with the BLAST program revealed that there are 61 amino acids (445 to 506) (precisely before the stop codon) homologous to alcohol de- 
hydrogenases (ADH) in mammalians and plants (Fig. 2B). This homologous region is within the ADH coenzyme binding domains (Dennis et al. 1985). In addition, a tyrosine kinase phosphorylation site (KEPEDDY) was found from amino acids 479 to 485 , which suggested that BWMK1 may be phosphorylated by a tyrosine kinase (Fig. 1; Cooper et al. 1984). These unique structures of $B W M K 1$ suggested that its biological function and mechanism of regulation might be different from those of the other members of the MAP kinase family.

\section{Genome organization of $B W M K 1$ in rice} and other plant species.

To determine the genome organization of $B W M K 1$ in rice, nuclear DNA of rice cultivars IR24, CO39, C101A51, C101LAC, C101PKT, TP309, and IR36 was digested with restriction enzymes BamHI, EcoRI, and PstI. The 350-bp cDNA fragment of $B W M K 1$ was used as a probe for Southern hybridization. It appears that $B W M K 1$ is a single-copy gene in the rice genome since only one hybridizing band was observed in all the cultivars digested with the three different restriction enzymes. No polymorphism was detected among the seven tested cultivars for these three enzymes (Fig. 3).

To localize the $B W M K 1$ gene in the rice genome, a double haploid (DH) population derived from a cross between indica rice cultivar IR64 and japonica cultivar Azucena was used (Huang et al. 1994). Eight restriction enzymes (BamHI, BglII, DraI, EcoRI, EcoRV, HindIII, PstI, and XbaI) were used to digest the two parental lines. Only PstI showed polymorphism between the two parental lines when the genomic clone of $B W M K 1(4.5 \mathrm{~kb})$ was used as a probe in Southern hybridization. One hundred and eleven DH lines were digested with PstI for mapping the gene. Mapping results indicated that $B W M K 1$ is located on chromosome 6 , where it is between the restriction fragment length polymorphism (RFLP) marker RG653 $(11.2 \mathrm{cM})$ and the amylose gene Amy2A $(14.0 \mathrm{cM})$ (data not shown; N. Huang, IRRI, personal communication).

Conservation of the $B W M K 1$ sequence in other plant species was investigated by hybridizing a garden blot with the

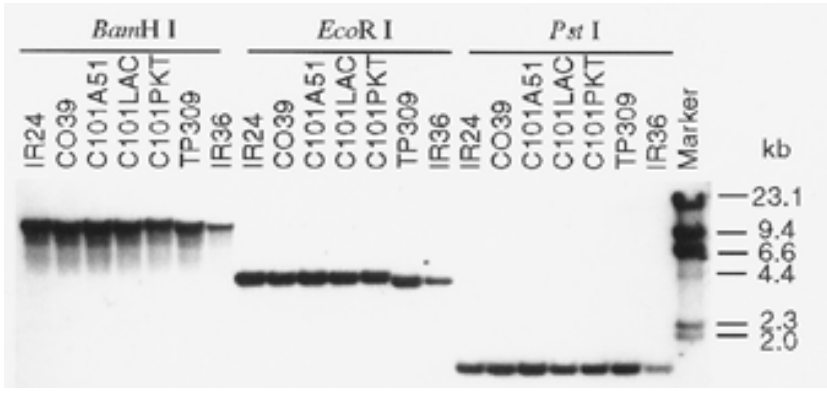

Fig. 3. Southern blot analysis of the $B W M K 1$ gene. Total genomic DNAs of eight rice lines ( $2 \mu \mathrm{g}$ each lane) were digested with three restriction enzymes (BamHI, EcoRI, and PstI) and probed with the 350-bp cDNA fragment. The DNA size marker $(\mathrm{kb})$ is lambda HindIII.

\begin{tabular}{|c|c|c|}
\hline & & \\
\hline & EASQYQIC & \\
\hline :P] & LFEVTAKYKPPILP. . . A. . I.CS.INSE.I, B, . . . A ARA.D & \\
\hline IPK & 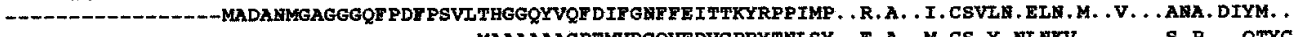 & \\
\hline 2 & 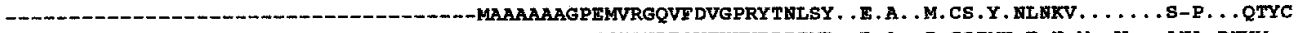 & \\
\hline RMK & GQP IQYWIFGNEFQVTKKYRPPIMP. .R.A. . I.CSIMH.E.N.M. .V. . .AHA. L & 80 \\
\hline and & ILERA, . . . LSRP. QRQTH. & 6.7 \\
\hline & III & \\
\hline IMIK1 & ILRE IKLLRLLRHPDIVE IKHIMLP- PSRREF QDIYVVFELMESDLHQVIRANDDLTPEHYQFFIYQLLRALKYIHAAKVF HRDLKPKEIL & \\
\hline IPK & 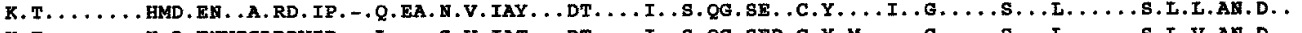 & \\
\hline IPK & 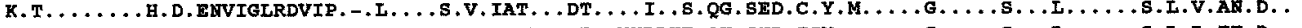 & \\
\hline RK2 & 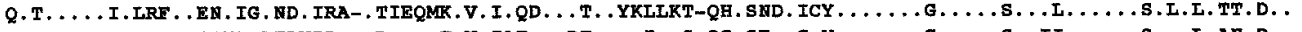 & \\
\hline RMK & 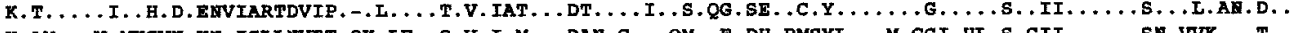 & \\
\hline NK1 1 & 1...DAM.C... & \\
\hline & * * & \\
\hline MK1 & PDAPSAIFWTDYV & \\
\hline PK & 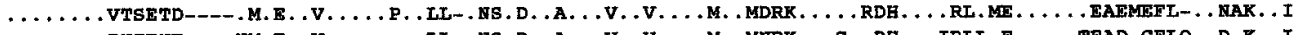 & \\
\hline PK & 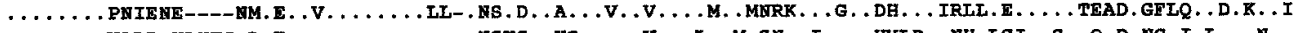 & \\
\hline & 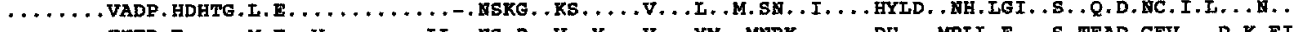 & \\
\hline $2 \mathrm{MK}$ & 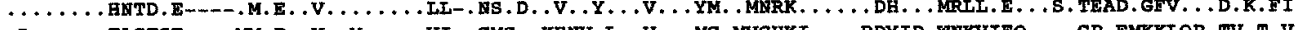 & \\
\hline MK1 & 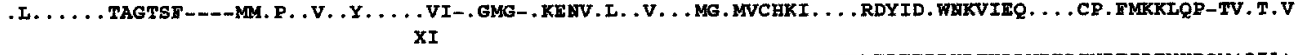 & \\
\hline & & \\
\hline & SLAPKI & \\
\hline & 2.A.SI & \\
\hline & & \\
\hline & & \\
\hline & GYS . EKL , PDVLFP , DSEHKK , KASQAR, LL, KMLVIDASKRI, VDEALQH. -YIMVWYL & \\
\hline
\end{tabular}

\begin{tabular}{|c|c|c|c|}
\hline 3IMK1 & 445 & AGQVEVTSTDLSSRSYLKSASISASKCVAVKDAKEPEDDY ISEEMEGSVDGLSEQVSRMES & 506 \\
\hline ADE1) & 214 & .ASRIIAV, INKDKF P. AKEVG. TE. INEQ.Y.K. IQEV.Q.ISD.G. .TSF.VIG. LDT & 277 \\
\hline HE) & 212 & . . AARI IGV. INKDKF A. AKEVG . TE. . MPQ.Y.K. IQEVLT.MSG, G. .FSF, VIG. LDT & 275 \\
\hline DHA ) & 214 & . . AARIIAV, IGKDKFA. AKELG. TE. IRPQ.Y.K IQEVLK.MTD.G. .FSF.VIG.LDT & $\mathbf{2 7 7}$ \\
\hline ADH2) & 16 & . ASRIIGV. I APAKYEQAKKFGCTEFVNPK. BDK. VQEVLI. LTH. G. . RSV.CT & 77 \\
\hline jidopsis & 216 & I. . ASRIIGV. FNSKRFDQAKETGVTE.VNPK. GDK. IQQV. A. MTD.G. .RSV.C & 277 \\
\hline
\end{tabular}

Fig. 2. Alignment of the deduced BWMK1 protein sequence with mitogen-activated protein (MAP) kinases and alcohol dehydrogenases. A, Multiple alignment of the deduced amino acid sequence (N-terminal) of BWMK1 with members of MAP kinases from other organisms. Amino acid sequences of SIPK and WIPK from tobacco, ERK2 (Owaki et al. 1992) from human, ERM from parsley, and JNK1 (Derijard et al. 1994) from human. Dot represents amino acid residues that match BWMK1. Gaps were induced to maximize alignment. The conserved TXY (in BWMK1, "X" is an aspartic acid while in other MAP kinase it is a glutamic acid or proline) phosphorylation motif for MAP kinase is indicated by asterisk. The 11 MAP kinase subdomains are labeled by roman numerals. B, Multiple alignment of the deduced amino acid sequence (C-terminal) of BWMK1 with other ADH in animals and plants; ADH1 (Hoog et al. 1993, Q03505) of rabbit, ADHE (Park and Plapp 1991, P00327) of horse, and ADHA (Matsuo and Yokoyama 1989, P07327) of human, ADH2 (Dennis et al. 1985) of maize, and ADH (Miyashita et al. 1996) of Arabidopsis. Dot represents amino acid residues that match BWMK1. 
$B W M K 1$ cDNA clone. The garden blot contained DNAs isolated from barley, goatgrass, maize, sorghum, wheat, alfalfa, potato, soybean, tomato, and Arabidopsis (kindly provided by J. Jiang, University of Wisconsin), and digested with the restriction enzyme HindIII. Except in potato and tomato, one to five hybridizing bands were observed among different species at low washing stringency $(2 \times \mathrm{SSC}[1 \times \mathrm{SSC}$ is $0.15 \mathrm{M} \mathrm{NaCl}$ plus $0.015 \mathrm{M}$ sodium citrate], $0.05 \% \mathrm{SDS}$ at $65^{\circ} \mathrm{C}$; data not shown), indicating that the sequences homologous to $B W M K 1$ are present among other plant species.

\section{$B W M K 1$ is induced by rice blast fungus as early as $4 \mathrm{~h}$ after inoculation.}

To assess the expression of $B W M K 1$ in the blast-infected rice plants, leaf tissues of C101A51 (blast resistant) were collected at different time points after inoculation. A RNA blot was hybridized with a ${ }^{32} \mathrm{P}$-labeled $B W M K 1$ full-length RTPCR cDNA clone. It was found that $B W M K 1$ was highly induced as early as $4 \mathrm{~h}$ after inoculation (Fig. 4A). The expression reached the highest level $8 \mathrm{~h}$ after inoculation and declined to the basal level $48 \mathrm{~h}$ after inoculation. The size of the hybridizing band was about $2.1 \mathrm{~kb}$, which was similar to the size of the full-length RT-PCR cDNA clone.

To test whether the induction of $B W M K 1$ expression was resistance gene specific, C101LAC (carrying Pil) and C101PKT (carrying Pi4) were inoculated with two incompatible Philippine isolates, 103 and 104, respectively. It was found that $B W M K 1$ was induced in both isogenic lines after blast inoculation (Fig. 4B, data for C101LAC not shown). To test for any difference between resistant and susceptible reactions, total RNA was isolated from leaves of the susceptible cultivar CO39 after inoculation with isolate 103. Northern (RNA) blot analysis indicated that the expression pattern of the $B W M K 1$ gene in this interaction was similar to that of the resistant plants of C101A51 (data not shown). These results suggested that the induction of the $B W M K 1$ gene was independent of rice blast resistance genes and resistance or susceptibility reactions.

\section{Induction of the $B W M K 1$ gene is independent of appressorium penetration.}

After inoculation, the blast spores germinate and produce the special infection structure the appressorium (Howard and Valent 1996). About 12 to $24 \mathrm{~h}$ after inoculation, the appressorium peg can penetrate the rice cell wall and enter the cell. To investigate whether the induction of $B W M K 1$ in the infected rice plants was caused by signaling molecules from the blast fungus or wounding created by penetration process of the appressorium, an appressorium-deficient mutant, nn78, of the blast fungus (Xu and Hamer 1996; kindly provided by J. Hamer, Purdue University) and its wild-type Guy11 were used to inoculate rice cultivar C039. One week after inoculation, typical susceptible lesions were observed in the plants of CO39 inoculated with Guy11 but not in plants inoculated with nn78. Total RNA was isolated from plants infected with both isolates at 0,8 , and $24 \mathrm{~h}$ after inoculation. $B W M K 1$ was induced in plants infected with both isolates $8 \mathrm{~h}$ after inoculation (Fig. 4C), suggesting that induction of $B W M K 1$ was independent of appressorium penetration and was probably due to signaling molecules secreted by the blast fungus during its spore germination and attachment on the rice leaf surface.
During blast inoculation, plants were sprayed with a spore suspension (containing $0.01 \%$ Tween 20 ) and transferred to a dew chamber for incubation at $100 \%$ humidity, $25^{\circ} \mathrm{C}$ for $24 \mathrm{~h}$. To investigate whether $B W M K 1$ was induced due to high humidity (requisite during the artificial inoculation procedure), lower temperature, or moving of the plants during inoculation, a control experiment was conducted in which water with $0.01 \%$ Tween 20 was sprayed on 3-week-old rice plants and total RNA was isolated at different time points. Northern blot analysis showed that there was no $B W M K 1$ induction in plants inoculated with water (Fig. 4D).

\section{$B W M K 1$ is induced by mechanical wounding.}

Some MAP kinases have been found to be activated in response to different stress signals, e.g., SAPK/JNK in mammals (Moriguchi et al. 1995 ) and SIPK in tobacco (Zhang and Klessig 1998a, 1998b). To test if $B W M K 1$ is also induced by abiotic stress, 3-week-old C101A51 plants were wounded mechanically and leaf tissues were harvested at different time points after the treatment. Northern blot analysis indicated that transcripts of $B W M K 1$ increased significantly $30 \mathrm{~min}$ after wounding and declined to the basal level within $2 \mathrm{~h}$ (Fig. 5). The effectiveness of the wounding treatment on rice leaves was confirmed by probing the same blot with $P O X 8.1$, a rice peroxidase gene that has been previously shown to be induced

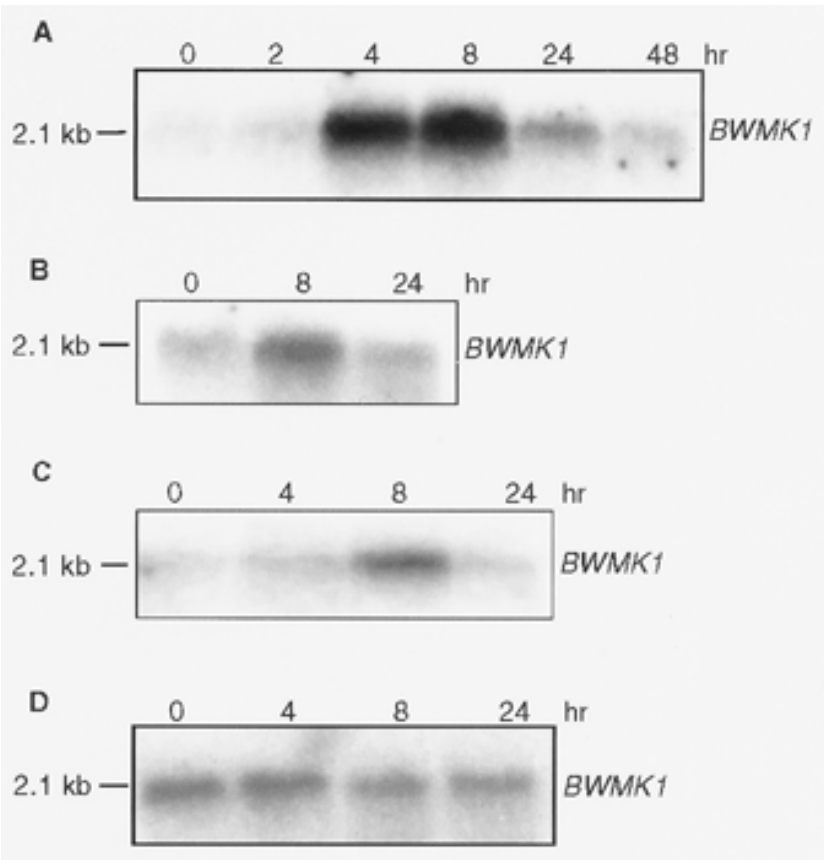

Fig. 4. Northern (RNA) blot analysis of the $B W M K 1$ gene after inoculation with blast isolates and water. A similar amount of total RNA was loaded in each lane and detected with a rice ribosomal DNA probe for all the Northern blots used in the following experiments (data not shown). A, Total RNA ( $20 \mu \mathrm{g}$ each lane) was isolated from rice leaf tissue of C101A51 at different time points after inoculation with Magnaporthe grisea isolate 103 . B, Total RNA (20 $\mu \mathrm{g}$ each lane) was isolated from rice leaf tissue of $\mathrm{C} 101 \mathrm{PKT}$ at different time points after inoculation with isolate 104. C, Total RNA ( $20 \mu \mathrm{g}$ each lane) was isolated from rice leaf tissue of $\mathrm{CO} 39$ at different time points after inoculation with an appressorium-deficient mutant nn78. D, Total RNA (20 $\mu \mathrm{g}$ each lane) was isolated from rice leaf tissue of C101A51 at different time points after being sprayed with water (0.01\% Tween 20$)$. All blots were probed with ${ }^{32}$ P-labeled $B W M K 1$. 
by wounding (Chittoor et al. 1997; kindly provided by J. Leach, Kansas State University). It was observed that POX8.1 was induced in the rice leaves $2 \mathrm{~h}$ after wounding (Fig. 5). These results suggest that $B W M K 1$ is not only responsive to pathogen infection but also involved in the initial step of the wound signaling pathway.

\section{Level of BWMK1 protein does not significantly increase after blast inoculation.}

The full-length cDNA of $B W M K 1$ was cloned in frame into the glutathione-S-transferase (GST) expression vector (Pharmacia, Cardiff, UK). The construct contained the entire open reading frame beginning with the ATG codon and ending with the stop codon of the cDNA fused to the vector sequence. The GST-BWMK1 fusion protein was induced and purified from Escherichia coli as described in Materials and Methods. SDS-polyacrylamide gel electrophoresis analysis of this purified recombinant BWMK1 protein revealed a protein with a molecular mass of about $60 \mathrm{kDa}$ (Fig. 6A) after cleaving with Factor Xa. This was found to be equivalent to the predicated size $(57.9 \mathrm{kDa})$ based on the DNA sequence with the software DNAStar. Antibody was raised against recombinant BWMK1 and used in immunoblot analysis. Four strong bands were detected (Fig. 6B). The size of one band $(60 \mathrm{kDa})$ was exactly the same as in the recombinant BWMK1 protein purified from E. coli. It was shown that the protein level of BWMK1 in rice leaf tissues does not significantly increase.

\section{BWMK1 can phosphorylate MBP in vitro.}

To investigate whether BWMK1 is a functional MAP kinase that could be activated by the blast fungus in rice leaves, an in-gel protein kinase assay was carried out with the total protein extracted from rice leaves at different time points
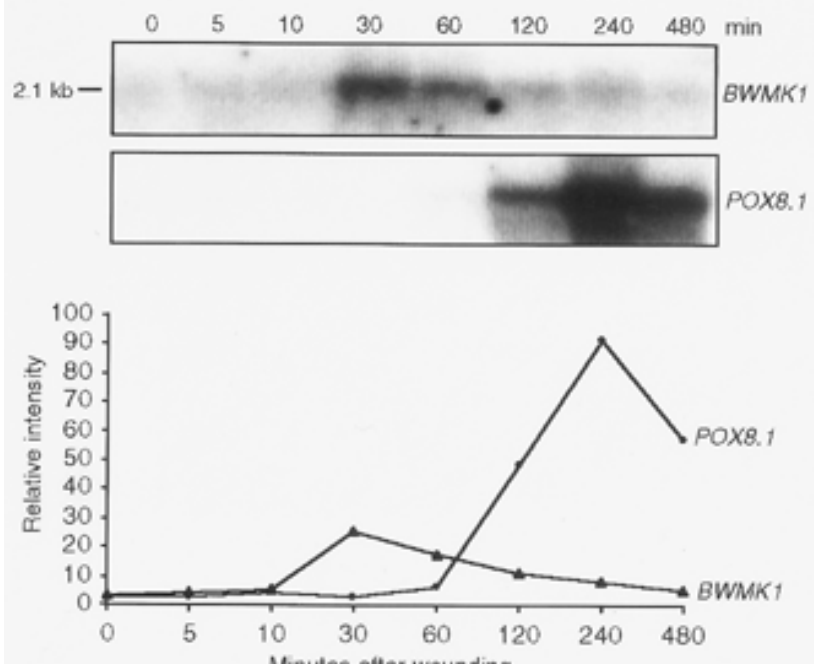

Fig. 5. Northern (RNA) blot analysis of the $B W M K 1$ gene after mechanical wounding. Total RNA ( $20 \mu \mathrm{g}$ each lane) was isolated from rice leaf tissue of C101A51 at different time points after wounding treatment. Blot was probed with ${ }^{32} \mathrm{P}$-labeled $B W M K 1$ (upper panel); the same blot was then re-hybridized with the rice peroxidase gene POX8.1 (middle panel). PhosphorImager quantification of BWMK1 and POX8.1 expression is shown (lower panel). A similar amount of total RNA loaded in each lane was detected with a rice ribosomal DNA probe (data not shown). after blast inoculation in which MBP was used as an artificial substrate (Erickson et al. 1990). Figure 6C (upper panel) shows that BWMK1 efficiently used MBP as an artificial substrate and the protein kinase activity was slightly increased, starting from $4 \mathrm{~h}$ after inoculation, peaking within $8 \mathrm{~h}$, and returned to the basal level after $24 \mathrm{~h}$. The size of the protein was $60 \mathrm{kDa}$, which was the same as the size of the recombi-
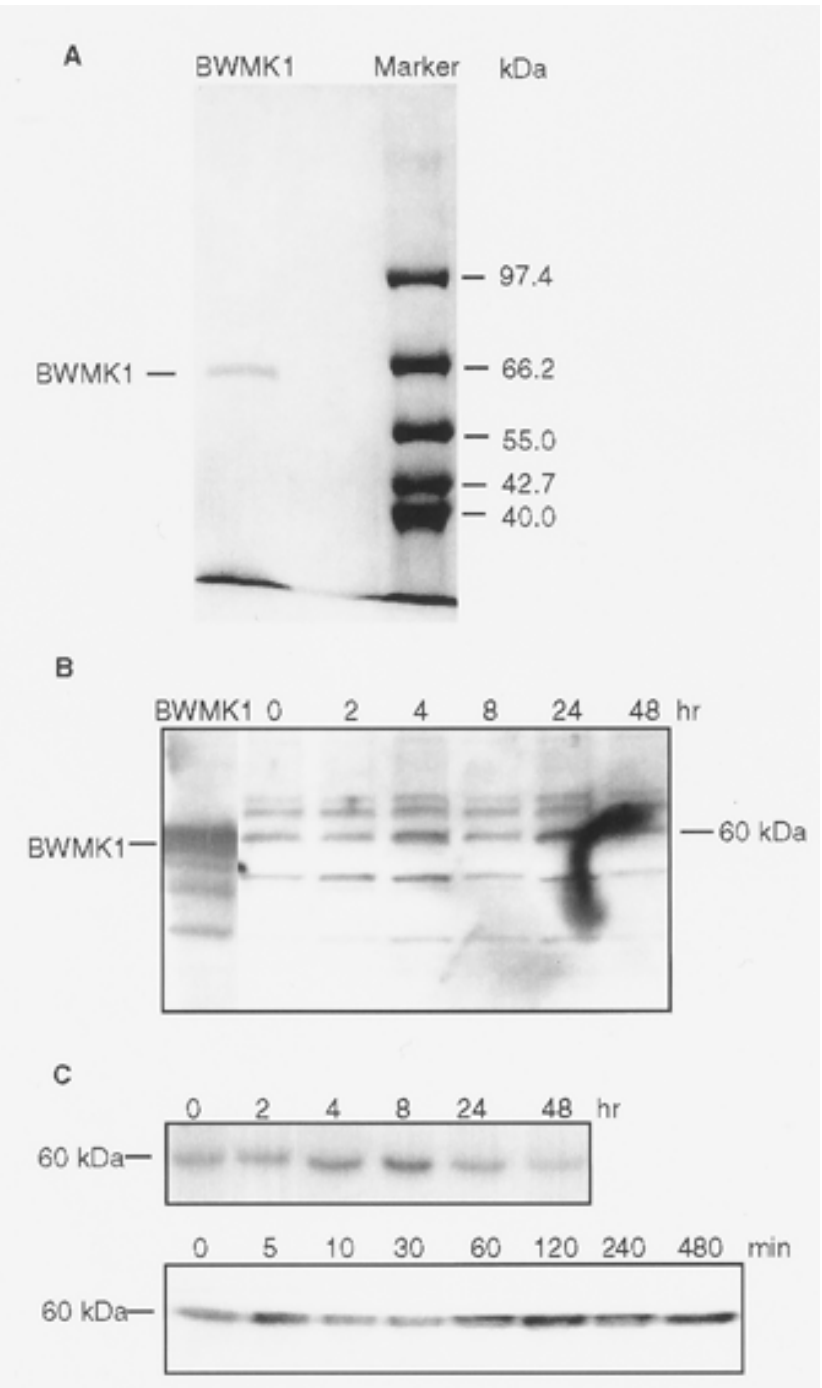

Fig. 6. Analysis of the BWMK1 fusion protein and in-gel kinase activity assays. A, A GST-BWMK1 fusion protein was cleaved with factor Xa and separated in a $7.5 \%$ sodium dodecyl sulfate-polyacrylamide gel electrophoresis (SDS-PAGE) gel. Protein size markers are indicated on the right. B, Western blot (immunoblot) analysis of BWMK1 with antiBWMK1 antibody. Total protein was extracted from rice leaf tissues of C101A51 at different time points $(0,4,8,12,24 \mathrm{~h})$ after inoculation with isolate 103 and was separated with a 10\% SDS-PAGE gel. Immunoblot analysis was carried out as described in Materials and Methods. The recombinant BWMK1 protein was purified from Escherichia coli as described in Materials and Methods. C, In-gel protein kinase assay. Total protein was extracted from rice leaf tissues of C101A51 at different time points after inoculation (upper) and from rice leaf tissues of C101A51 at different time points after mechanical wounding (lower). Proteins were separated with a $10 \%$ SDS-PAGE gel. MBP $(0.25 \mathrm{mg} / \mathrm{ml})$ was used as a substrate and was polymerized in the polyacrylamide gel. After renaturation, kinase reactions were carried out in gel with $\left[\gamma^{32} \mathrm{P}\right]$ adenosine $5^{\prime}$-triphospate (ATP) as described in Materials and Methods. 
nant BWMK1 protein. An in-gel kinase analysis was also carried out to test if wounding could also increase the enzymatic activity of BWMK1. A $60-\mathrm{kDa}$ band was observed whose intensity remained unchanged after the wounding treatment (Fig. 6C, lower panel). Even though a slight increase of protein activity was observed in blast-infected leaves but not in wound-treated leaves, further experiments are needed to confirm if BWMK1 is activated at post-translational level by both fungal infection and mechanical wounding.

\section{Phosphorylated BWMK1 can be detected by anti-phosphotyrosine monoclonal antibody.}

Another hallmark of MAP kinases is their activation via dual phosphorylation of tyrosine and threonine residues by MAP kinase kinases (Seger and Krebs 1995). To further confirm whether BWMK1 is a MAP kinase and can be phosphorylated by its upstream kinase, immunoprecipitation and Western blot (immunoblot) analyses were carried out. BWMK1 was first isolated by immunoprecipitation with the anti-BWMK1 antibody. The anti-phosphotyrosine monoclonal antibody 4G10 was used to detect the phosphorylated BWMK1. As shown in Figure 7, the size of phosphorylated protein is about $60 \mathrm{kDa}$, which is same as that of BWMK1. Together with the MBP in-gel analysis, these analyses confirmed that BWMK1 is a functional MAP kinase in rice.

\section{DISCUSSION}

Plants are constantly exposed to a variety of biological and nonbiological stresses in natural conditions. To cope with such stresses, plants have developed sophisticated self-defense system in which concerted modulation of gene expression is performed (Hammond-Kosack and Jones 1996). Several lines of evidence have demonstrated that MAP kinase cascades are involved in the rapid activation of transcription factors in response to stress signals in plants (Hirt 1997; Somssich 1997). During the last few years, several MAPKs have been identi-

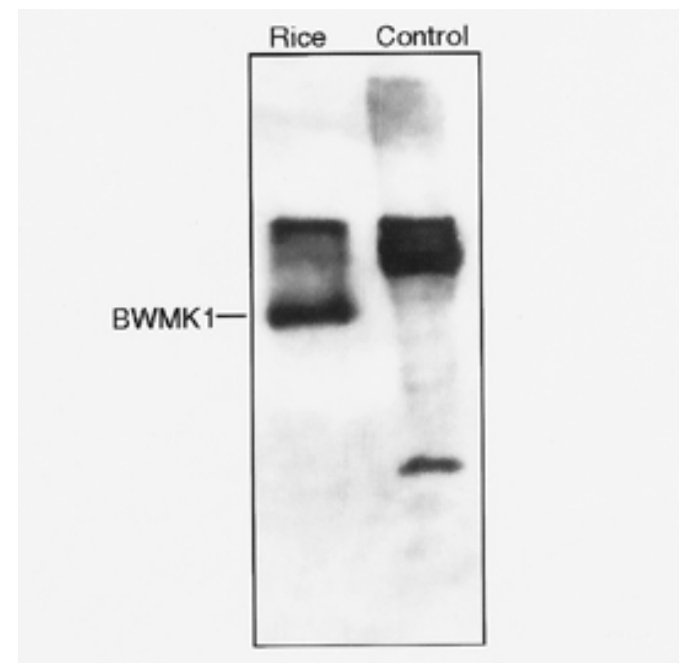

Fig. 7. Phosphorylation of tyrosine residues of BWMK1. Rice total cell extracts were immunoprecipitated with anti-BWMK1 antibody and Western blot (immunoblot) was carried out with phosphotyrosinespecific monoclonal antibody $4 \mathrm{G} 10$. A major band $60 \mathrm{kDa}$ in size was detected. EGF-stimulated A431 cell lysate was used as a positive control. fied, from different dicot plant species, that are responsive to diverse stresses (Seo et al. 1995; Jonak et al. 1996; Bogre et al. 1997; Ligterink et al. 1997; Zhang and Klessig 1997, 1998a, 1998b). In this report, we show that the rice MAP kinase gene $B W M K 1$ is strongly induced by blast infection and by mechanical wounding, similar to the two tobacco MAP kinase genes SIPK and WIPK (Zhang and Klessig 1999). SIPK activation is exclusively post-translational via tyrosine and threonine/serine phosphorylation. In contrast to SIPK, we have shown that BWMK1 was induced strongly at the mRNA level and slightly at the post-translational level by blast infection, which is similar to WIPK. However, the expression kinetics of BWMK1 and WIPK are different. The transcripts of $W I P K$ began to accumulate as early as 1 min after wounding, whereas the transcripts of $B W M K 1$ can only be detected about 30 min after mechanical wounding. The reaction of these two MAP kinases to pathogen infection is also different. The activation of the WIPK gene is resistance gene $N$ dependent, but the induction of $B W M K 1$ is not disease resistance gene dependent. It can be activated by both compatible and incompatible blast isolates. These results support that BWMK1 is a new member of plant MAP kinase family.

Compared with other cloned plant MAP kinases structurally, BWMK1 has its uniqueness. First, BWMK1 has a new dual-phosphorylation activation motif TDY that has not been reported in mammalian and plant MAP kinases. It might be a functional homolog of the mammalian MAP kinases SAPK/JNK and p38, which are activated by several distinct stimuli (Kyriakis and Avruch 1996). These two MAP kinases have unique dual-phosphorylation motifs (TPY and TGY, respectively), compared with the classical MAP kinases, which contain a TEY motif (Seger and Krebs 1995). The sequence of the activation site was reported to be important to their function (Jiang et al. 1997) and is considered to be the hallmark for the classification of mammalian MAP kinases (Kyriakis and Avruch 1996). Even though amino acids aspartic acid and glutamate belong to the same group (negatively charged $\mathrm{R}$ group), the aspartic acid in the BWMK1 activation site may have a different function in response to environmental stresses. Second, BWMK1 is the largest plant MAP kinase reported so far and contains 150 unique amino acids in its $\mathrm{C}$ terminus, in which a domain homologous to ADH coenzyme binding domains and a tyrosine kinase phosphorylation site was found. ADH is present in many organisms that metabolize ethanol, and is involved in an oxidoreductase reaction with $\mathrm{NAD}^{+} / \mathrm{NADH}$ as an essential co-factor. In plants, it has been shown that the $\mathrm{ADH}$ gene was induced by a number of environmental stresses, including low oxygen, dehydration, low temperature, arachidonic acid elicitor, or anaerobiosis treatments (Dolferus et al. 1994; Matton et al. 1990). Whether the $\mathrm{ADH}$-like domain of BWMK1 has a similar function in rice cells after blast infection and wounding needs further investigation. The presence of a tyrosine kinase phosphorylation site may suggest that BWMK1 is phosphorylated not only by BWMK1 kinase but also by a tyrosine kinase during blast infection and mechanical wounding. Based on its unique structure, we reason that BWMK1 is a novel MAP kinase that may have a different regulation mechanism in response to stress signals.

One of the important features of MAP kinase signal transduction pathways identified in yeast and mammals is that they 
diverge and converge, thus allowing different but overlapping responses to be triggered under different circumstances (Lewin 1997). Convergence is illustrated by the ability of different types of MAP kinases to initiate signals leading to the activation of the same pathway (Hunter 1995). For example, the SAPK/JNK and the p38 kinase in mammals can be activated by heat, osmotic stress, pathogen components, and proinflammatory signals. It is not clear how a given MAP kinase pathway can be activated by different signals. Similar to the tobacco MAP kinase genes SIPK and WIPK, we found that $B W M K 1$ was activated by both fungal infection and mechanical wounding. The mechanism of $B W M K 1$ activation by two unrelated signals needs to be further investigated. Recent reports have demonstrated that the wound and pathogen response pathways may be functionally related in plants (Penninckx et al. 1996; Schweizer et al. 1998). Wounding of one leaf of rice plants caused the nontreated leaf of wounded plants to be more resistance to challenge infection by the blast fungus and it was also shown that local application of jasmonic acid, the putative signal of the wound response, resulted in systemic resistance to a similar degree as resulted from wounding (Schweizer et al. 1998). Therefore, it is possible that wounding and infection in rice activate defense genes through an analogous mechanism.

Blast fungus infects rice plants in a manner typical of other foliar pathogens. Infection by $M$. grisea is initiated when a conidium lands on the leaf surface. In a drop of water, the conidium produces a germ tube that grows and differentiates into a specialized infection structure called an appressorium that adheres tightly to the leaf surface (Bourett and Howard 1990). The time required for formation of the appressorium peg after inoculation is at least $12 \mathrm{~h}$. However, $B W M K 1$ was activated as early as $4 \mathrm{~h}$ post inoculation, suggesting that its activation may be triggered by spore attachment or certain stimulants secreted by the fungus. To test our speculation, we inoculated rice plants with an appressorium-deficient mutant (nn78) and monitored the induction of $B W M K 1$ in the plants after inoculation. The experiment showed that $B W M K 1$ was also induced in plants infected with the mutant isolate, indicating that activation of the $B W M K 1$ gene in rice was not due to appressorium penetration. However, it is not currently known what substance secreted from the fungus is the signaling molecule. It has been reported that $E R M K$ of parsley and $S I P K$ of tobacco were induced by several nonspecific fungal elicitors in suspension cells (Ligterink et al. 1997; Zhang et al. 1998). Inoculating rice plants or treating rice suspension cells with cell-free extracts of blast fungus or fungal elicitors isolated from other plant pathogens may provide information about whether $B W M K 1$ is responsive to fungal elicitor(s) or other chemicals.

\section{MATERIALS AND METHODS}

\section{Rice blast inoculation and mechanical wounding.}

The blast-resistant, near-isogenic line C101LAC (carrying Pi1), C101A51 (carrying Pi2), C101PKT (carrying Pi4), and the susceptible, recurrent cultivar CO39 (Mackill and Bonman 1992), and four blast isolates, i.e. 103 (PO6-6), 104 (PO3-8251), Guy11, and nn78, were used in the inoculation experiments. Three-week-old rice plants were inoculated with different isolates. The inoculated plants were kept in a dew chamber for $24 \mathrm{~h}$ at $26^{\circ} \mathrm{C}$ and subsequently transferred to a growth chamber at $12 \mathrm{~h}$ light, $12 \mathrm{~h}$ dark, and 25 to $26^{\circ} \mathrm{C}$ for 7 days. Leaf tissues were harvested from the cultivars at different time points after inoculation. Mechanical wounding was carried out with leaves of 3-week-old C101A51 plants. Three leaves were extruded with the use of two pieces of plastic boards for $5 \mathrm{~s}$ and were harvested at different time points.

\section{RNA isolation, cDNA synthesis, and RT-PCR.}

An RNeasy mini kit (Qiagen, Hilden, Germany) was used to isolate total RNA from 150 to $200 \mathrm{mg}$ of rice leaf tissue. $\operatorname{Poly}(\mathrm{A})^{+}$RNA fractionated from total RNA, with a Qiagen Oligotex Spin Column, was used as a template in an RT-PCR. Two primers, CF9-RT and CF9-Rev, were designed based on the DNA sequence of the $C f-9$ gene, a tomato resistance gene to the leaf mold fungus $C$. fulvum (Jones et al. 1994). The primer sequence of CF9-RT is 5'-AAAAGCACAAGTTGCT GC-3', which is the DNA sequence 217 to 235 bp after the start codon. The sequence of CF9-Rev is 5'-TAACGTCT ATCGACTTCT-3', which is the reverse-strand sequence of $C f-9$ from 1426 to 1408 bp. For isolation of the full-length cDNA of $B W M K 1$, two primers were designed (BWMK1-F1 and BWMK1-R1). Primer BWMK1-F1 (5'-AACACAGTGG AAATGGAGTTCTTCA-3') corresponds to the sequence spanning the ATG codon (underlined, Fig. 1). BWMK1-R1 (5'-GAATGGATCACTGTCTCAGCAGTTC -3') corresponds to the sequence 1923 to 1948 in Fig. 1. RT-PCR was carried out according to the protocols provided by the manufacturer (GIBCO-BRL, Gaithersburg, MD). The amplified cDNAs were then separated in a $1.2 \%$ agarose gel.

\section{Cloning and DNA sequencing.}

Specific bands were cloned into a pGEM-T vector according to the manufacturer's instructions (Promega, Madison, WI). Nucleotide sequencing were performed with the ABI PRISM 377 DNA sequencer (Perkin-Elmer, Foster city, CA). The sequence was analyzed with the software DNAstar (DNAstar, Madison, WI) and Sequencher 3.0 (Gene Codes, Ann Arbor, MI).

\section{BAC library screening.}

Protocols for the BAC filter preparation and screening were as described by Wang et al. (1995). Hybridization and washing conditions were the same, as described in Hoheisel et al. (1993).

\section{Construction of a cDNA library from rice.}

Rice leaf tissues were harvested at 2, 4, and $8 \mathrm{~h}$ after inoculation with isolate 103. mRNA was isolated with an mRNA isolation kit (Boehringer Mannheim, Mannheim, Germany). A cDNA library was constructed with the SuperScript Plasmid System (GIBCO-BRL), according to the manufacturer's instructions. The cDNA library was screened with the 350-bp cDNA fragment obtained from the degenerate RT-PCR. The cDNA clones were confirmed by Southern blot and sequence analysis.

\section{Southern and Northern hybridization.}

Rice genomic DNA was isolated as described by Dellaporta et al. (1984). DNA was digested with restriction enzymes and resolved on an $0.8 \%$ agarose gel, and then transferred onto 
Hybond- $\mathrm{N}^{+}$membrane (Amersham, Buckinghamshire, UK). Probes were labeled with a megaprimer labeling kit (Amersham). Rapid hybridization solution (Clonetech, Palo Alto, CA) was used.

Total RNA used in the Northern blot analysis was isolated with the Trizol total RNA isolation reagent (GIBCO-BRL). About $20 \mu \mathrm{g}$ of total RNA per lane was separated in a $1.0 \%$ agarose gel and transferred onto Hybond- $\mathrm{N}^{+}$membrane (Amersham) with a NorthernMax kit (Ambion, Austin, TX) according to the manufacturer's instructions. Northern blot hybridization was carried out in the same way as the Southern hybridization described above.

\section{Preparation of protein extracts.}

About $1 \mathrm{~g}$ of leaf tissue was ground into a fine powder in liquid nitrogen and two volumes (wt/vol) of extraction buffer (100 mM HEPES [ $N$-2-hydroxyethylpiperazine- $N$-2-ethanesulfonic acid], pH 7.5, $5 \mathrm{mM}$ EDTA, $5 \mathrm{mM}$ EDTG, $10 \mathrm{mM}$ DTT [dithiothreitol], $10 \mathrm{mM} \mathrm{Na} \mathrm{VO}_{4}, 10 \mathrm{mM} \mathrm{NaF}, 50 \mathrm{mM} \beta$ glycerophosphate, $1 \mathrm{mM}$ phenylmethysulfonyl fluoride, $5 \mu \mathrm{g}$ of antipain per $\mathrm{ml}, 5 \mu \mathrm{g}$ of aprotinin per $\mathrm{ml}, 5 \mu \mathrm{g}$ of leupeptin per $\mathrm{ml}, 10 \%$ glycerol, $7.5 \%$ polyvinylpolypyrrolidone) was added. After centrifugation at 13,000 rpm $(17,900 \times \mathrm{g} ; 5417 \mathrm{C}$ model centrifuge; Eppendorf, Hamburg, Germany) for $20 \mathrm{~min}$, the supernatant was transferred into clean tubes, quickly frozen in liquid nitrogen, and stored at $-80^{\circ} \mathrm{C}$.

\section{Protein concentration assay.}

The concentration of proteins was determined with the BioRad protein assay kit (Bio-Rad, Hercules, CA), with BSA (bovine serum albumin) as the standard.

\section{Antibody production and immunoblot analysis.}

A polyclonal antiserum was raised against recombinant BWMK1. Protein samples were separated by electrophoresis on $10 \%$ SDS-polyacrylamide gel and transferred onto PVDF (polyvinylidene difluoride) membrane (BioRad) in a solution containing $25 \mathrm{mM}$ Tris, $192 \mathrm{mM}$ glycine, $20 \%$ (vol/vol) methanol, $\mathrm{pH} 8.3$. After blocking with $5 \%$ milk, $0.1 \%$ Tween 20 in $1 \times$ TBS ( 1 liter of $1 \times$ TBS: $2.42 \mathrm{~g}$ of Tris base, $8.0 \mathrm{~g}$ of $\mathrm{NaCl}, \mathrm{pH}$ 7.6) for $1 \mathrm{~h}$, membranes were incubated with the anti-BWMK1 antibody at dilution 1:2,000 overnight at $4{ }^{\circ} \mathrm{C}$ and washed 3 times with $1 \times$ TBS containing $0.1 \%$ Tween 20 . The membranes were incubated with HRP-conjugated secondary antibody $(1: 1,500)$ (New England Biolabs, Beverly, MA) in $1 \times$ TBS with $5 \%$ milk, $0.1 \%$ Tween 20 for $1 \mathrm{~h}$ at room temperature. After washing as described above, a membrane was detected with $10 \mathrm{ml}$ of LumiGLO $(0.5 \mathrm{ml}$ of $20 \times \mathrm{Lu}-$ miGLO, $0.5 \mathrm{ml}$ of $20 \times$ peroxide, and $9.0 \mathrm{ml}$ of Milli-Q water) for $1 \mathrm{~min}$ at room temperature. The membranes were exposed to X-ray film for several seconds.

\section{In-gel kinase activity assay.}

The in-gel kinase assay was performed as described by Zhang and Klessig (1997) with some modifications. Briefly, extracts containing $10 \mu \mathrm{g}$ of total protein were electrophoresed on a $10 \%$ SDS-polyacrylamide gel embedded with $0.25 \mu \mathrm{g}$ of MBP per ml (18.5 kDa; GIBCO-BRL) used as a substrate. The gel was washed at room temperature three times with washing buffer (25 mM Tris, pH 7.5, $0.5 \mathrm{mM}$ DTT, $0.1 \mathrm{mM}$ $\mathrm{Na}_{3} \mathrm{VO}_{4}, 5 \mathrm{mM} \mathrm{NaF}, 0.5 \mathrm{mg}$ of BSA per ml, $0.1 \%$ Triton X-
100 [vol/vol]), each for $30 \mathrm{~min}$. The kinases were allowed to re-nature in $25 \mathrm{mM}$ Tris $\mathrm{pH}$ 7.5, $2 \mathrm{mM}$ EGTA, $12 \mathrm{mM} \mathrm{MgCl}_{2}$, $1 \mathrm{mM}$ DTT, $0.1 \mathrm{mM} \mathrm{Na}_{3} \mathrm{VO}_{4}$, and $5 \mathrm{mM} \mathrm{NaF}$ at $4{ }^{\circ} \mathrm{C}$ overnight with three changes of buffer. The gel was then incubated at room temperature in $30 \mathrm{ml}$ of reaction buffer $(25 \mathrm{mM}$ Tris, pH 7.5, 2 mM EGTA, $10 \mathrm{mM} \mathrm{MgCl}_{2}, 1 \mathrm{mM}$ DTT, $0.1 \mathrm{mM}$ $\mathrm{Na}_{3} \mathrm{VO}_{4}$ ) with $200 \mathrm{nM}$ ATP plus $50 \mu \mathrm{Ci} \gamma_{-}{ }^{32} \mathrm{P}$-ATP for $60 \mathrm{~min}$. The gel was treated with $5 \%$ trichloroacetic acid (TCA), (wt/vol)/1\% NaPPi (wt/vol) to terminate the reaction and incubated at room temperature for $12 \mathrm{~h}$ with five changes of the solution. The gel was dried onto Whatman 3MM paper and exposed to Kodak BIOMAX film. Prestained size marker (New England Biolabs) was used to calculated the size of kinases.

\section{Immunoprecipitation with anti-BWMK1 antibody and immunoblot analysis with the anti-phosphotyrosine antibody.}

Eight hundred microliters of protein extracts was incubated with $50 \mu \mathrm{l}$ of anti-BWMK1 antibody at $4^{\circ} \mathrm{C}$ with shaking overnight and then $50 \mu \mathrm{l}$ of protein A Sepharose bead was added and incubated at $4^{\circ} \mathrm{C}$ for $2 \mathrm{~h}$. The Sepharose bead was collected and washed three times in ice-cold phosphatebuffered saline buffer. The bead was resuspended in protein sample buffer and separated on 10\% SDS-polyacrylamide gel. Epidermal growth factor (EGF)-stimulated A431 cell lysate was used as a positive control. The proteins were transferred to PVDF membrane by electroblotting. The membrane was blocked and incubated with the phosphotyrosine-specific monoclonal antibody 4G10 with an Anti-Phosphotyrosine Western Blotting Kit (Upstate Biotechnology, Lake Placid, $\mathrm{NY}$ ), following the manufacturer's instructions.

\section{ACKNOWLEDGMENTS}

We thank N. Naqvi for providing the CF9 primers and J. Hamer for providing the blast fungus mutant nn78, N. Huang for the IR64 BAC library, and H. Leung for the DH mapping population. We are grateful to J. Lee, N. Naqvi, and H. Leung for their critical reading of the manuscript.

\section{LITERATURE CITED}

Bogre, L., Ligterink, W., Meskiene, I., Barker, P., Heberle-Bors, E., Huskisson, N. S., and Hirt, H. 1997. Wounding induces the rapid and transient activation of a specific kinase pathway. Plant Cell 9: 75-83.

Bourett, T. M., and Howard, R. J. 1990. In vitro development of penetration structures in the rice blast fungus Magnaporthe grisea. Can. J. Bot. 68:329-342.

Chittoor, J. M., Leach, J. E., and White, F. F. 1997. Differential induction of a peroxidase gene family during infection of rice by Xanthomonas oryzae pv. oryzae. Mol. Plant-Microbe Interact. 10:861-871

Cooper, J. A., Esch, F. S., Taylor, S. S., and Hunter T. 1984. Phosphorylation sites in enolase and lactate dehydrogenase utilized by tyrosine protein kinases in vivo and in vitro. J. Biol. Chem. 259:7835-7841.

Dellaporta, S. L., Wood, J., and Hicks, J. B. 1984. Pages 36-37 in: Molecular Biology of Plants: A Laboratory Course Manual. M. Russell, ed. Cold Spring Harbor Laboratory, Cold Spring Harbor, NY.

Dennis, E. S., Sachs, M. M., Gerlach, W. L., Finnegan, E. J., and Peacock, W. J. 1985. Molecular analysis of the alcohol dehydrogenase 2 (Adh2) gene of maize. Nucleic Acids Res. 13:727-43.

Derijard, B., Hibi, M., Wu, I. H., Barrett, T., Su, B., Deng, T., Karin, M., and Davis, R. J. 1994. JNK1: A protein kinase stimulated by UV light and Ha-Ras that binds and phosphorylates the c-Jun activation domain. Cell 76:1025-1037. 
Dolferus, R., Jacobs, M., Peacock, W. J., and Dennis, E. S. 1994. Differential interactions of promoter elements in stress responses of the Arabidopsis Adh gene. Plant Physiol. 105:1075-1087.

Erickson, A. K., Payne, D. M., Martino, P. A., Rossomando, A. J., Shabanowitz, J., Weber, M. J., Hunt, D. F., and Sturgill, T. W. 1990. Identification by mass spectrometry of threonine 97 in bovine myelin basic protein as a specific phosphorylation site for mitogen-activated protein kinase. J. Biol. Chem. 265:19728-19735.

Hammond-Kosack, K. E., and Jones, J. D. G. 1996. Resistance genedependent plant disease responses. Plant Cell 8:1773-1791.

Hanks, S. K., and Quinn, A. M. 1991. Protein kinase catalytic domain sequence database: Identification of conserved features of primary structure and classification of family members. Methods Enzymol. 200:38-62.

Hirt, H. 1997. Multiple roles of MAP kinases in plant signal transduction. Trends Plant Sci. 2:11-15.

Hoheisel, J. D., Maier, E., Mott, R., McCarthy, L., Grigoriev, A. V., Schalkwyk, L. C., Nizetic, D., Francis, F., and Lehrach, H. 1993. High resolution cosmid and $\mathrm{P} 1$ maps spanning the $14 \mathrm{Mb}$ genome of the fission yeast $S$. pombe. Cell 73:109-120.

Hoog, J. O., Vagelopoulos, N., Yip, P. K., Keung, W. M., and Jornvall, H. 1993. Isozyme developments in mammalian class-I alcohol dehydrogenase: cDNA cloning, functional correlations, and lack of evidence for genetic isozymes in rabbit. Eur. J. Biochem. 213:31-38.

Howard, R. J., and Valent, B. 1996. Breaking and entering: Host penetration by the fungal rice blast pathogen Magnaporthe grisea. Annu. Rev. Microbiol. 50:491-512.

Huang, N., McCouch, S., Mew, T., Parco, A., and Guiderdoni, E. 1994. Development of an RFLP map from a doubled haploid population in rice. Rice Genet. Newsl. 11:134-137.

Hunter, T. 1995. Protein kinases and phosphatases: The yin and yang of protein phosphorylation and signaling. Cell 80:225-236.

Jiang, Y., Li, Z., Schwarz, E. M., Lin, A., Guan, K., Ulevitch, R. J., and Han, J. 1997. Structure-function studies of p38 mitogen-activated protein kinase: Loop I2 influences substrate specificity and autophosphorylation, but not upstream kinase selection. J. Biol. Chem. 272: 11096-11102.

Jonak, C., Kiegerl, S., Ligterink, W., Barker, P. J., Huskisson, N. S., and Hirt, H. 1996. Stress signaling in plants: A mitogen-activated protein kinase pathway is activated by cold and drought. Proc. Natl. Acad. Sci. USA 93:11274-11279.

Jones, D. A., Thomas, C. M., Hammond-Kosack, K. E., Balint-Kurti, P. J., and Jones, J. D. 1994. Isolation of the tomato $C f-9$ gene for resistance to Cladosporium fulvum by transposon tagging. Science 266 : 89-793.

Kato, Y., Kravchenko, V. V., Tapping, R. I., Han, J., Ulevitch, R. J., and Lee, J. D. 1997. BMK1/ERK5 regulates serum-induced early gene expression through transcription factor MEF2C. EMBO J. 16:70547066.

Kyriakis, J. M., and Avruch, J. 1996. Protein kinase cascades activated by stress and inflammatory cytokines. BioEssays 18:567-577.

Lee, J. D., Ulevitch, R. J., and Han, J. 1995. Primary structure of BMK1: A new mammalian map kinase. Biochem. Biophys. Res. Commun. 213:715-724.

Lewin, B. 1997., Chapter 35, Signal transduction. Pages 1053-1087 in: Gene VI. Oxford University Press, Oxford..

Ligterink, W., Krol, T., zur Nieden, U., Hirt, H., and Scheel, D. 1997. Receptor-mediated activation of a MAP kinase in pathogen defense of plants. Science 276:2054-2057.

Mackill, D. J., and Bonman, J. M. 1992. Inheritance of blast resistance in near-isogenic lines of rice. Phytopathology 82:746-749.

Marshall, C. J. 1994. MAP kinase kinase kinase, MAP kinase kinase and MAP kinase. Curr. Opin. Genet. Dev. 4:82-89

Matsuo, Y., and Yokoyama, S. 1989. Molecular structure of the human alcohol dehydrogenase 1 gene. FEBS Lett. 243:57-60.

Matton, D. P., Constabel, P., and Brisson, N. 1990 Alcohol dehydrogenase gene expression in potato following elicitor and stress treatment. Plant Mol. Biol. 14:775-783.
Miyashita, N. T., Innan, H., and Terauchi, R. 1996. Intra- and interspecific variation of the alcohol dehydrogenase locus region in wild plants Arabis gemmifera and Arabidopsis thaliana. Mol. Biol. Evol. 13:433-6.

Moriguchi, T., Kawasaki, H., Matsuda, S., Gotoh, Y., and Nishida, E. 1995. Evidence for multiple activators for stress-activated protein kinase/c-Jun amino-terminal kinases. Existence of novel activators. J. Biol. Chem. 270:12969-12972.

Ou, S. H. 1985. Rice Disease. 2nd ed. The Cambrian News, Kew, U.K. pp. 109-201.

Owaki, H., Makar, R., Boulton, T. G., Cobb, M. H., and Geppert, T. D. 1992. Extracellular signal-regulated kinases in T cells: Characterization of human ERK1 and ERK2 cDNAs. Biochem. Biophys. Res. Commun. 82:1416-1422.

Park, D. H, and Plapp, B. V. 1991. Isoenzymes of horse liver alcohol dehydrogenase active on ethanol and steroids, cDNA cloning, expression, and comparison of active sites. J. Biol. Chem. 266:13296-13302.

Penninckx, I. A., Eggermont, K., Terras, F. R., Thomma, B. P., De Samblanx, G. W., Buchala, A., Metraux, J. P., Manners, J. M., and Broekaert, W. F. 1996. Pathogen-induced systemic activation of a plant defensin gene in Arabidopsis follows a salicylic acid-independent pathway. Plant Cell 8:2309-2323

Romeis, T., Piedras, P., Zhang, S., Klessig, D. F., Hirt, H., and Jones, J. D. G. 1999. Rapid Avr9- and $C f$-9-dependent activation of MAP kinases in tobacco cell cultures and leaves: Convergence of resistance gene, elicitor, wound, and salicylate responses. Plant Cell 11:273-287.

Schweizer, P., Buchala, A., Dudler. R., and Metraux, J. P. 1998. Induced systemic resistance in wounded rice plants. Plant J. 14:475-481.

Seo, S., Okamoto, M., Seto, H., Ishizuka, K., Sano, H., and Ohashi, Y. 1995. Tobacco MAP kinase: A possible mediator in wound signal transduction pathways. Science 270:1988-1992.

Seger, R., and Krebs, E. G. 1995. The MAP kinase signaling cascade. FASEB J. 9:726-735.

Somssich, I. E. 1997. MAP kinases and plant defence. Trends Plant Sci. 2:406-408.

Usami, S., Banno, H., Ito, Y., Nishihama, R., and Machida, Y. 1995. Cutting activates a 46-kilodalton protein kinase in plants. Proc. Natl. Acad. Sci. USA 92:8660-8664.

Wang, G. L., Holsten, T. E., Song, W. Y., Wang, H. P., and Ronald, P. C. 1995. Construction of a rice bacterial artificial chromosome library and identification of clones linked to a disease resistance locus. Plant J. 7:525-533.

Xu, J. R., and Hamer, J. 1996. MAP kinase and cAMP signaling regulate infection structure formation and pathogenic growth in the rice blast fungus Magnaporthe grisea. Genes Dev. 10:2696-2706.

Yang, D., Parco, A., Nandi, S., Subudhi, S., Zhu, Y. G., Wang, G. L., and Huang, N. 1997. Construction of a bacterial artificial chromosome (BAC) library and identification of overlapping BAC clones with chromosome 4-specfic RFLP markers in rice. Theor. Appl. Genet. 95: 1147-1154.

Zhang, S., Du, H., and Klessig, D. F. 1998. Activation of the tobacco SIP kinase by both a cell wall-derived carbohydrate elicitor and purified proteinaceous elicitins from Phytophthora spp. Plant Cell 10: 435-450.

Zhang, S., and Klessig, D. F. 1997. Salicylic acid activates a 48-kDa MAP kinase in tobacco. Plant Cell 9:809-824.

Zhang, S., and Klessig, D. F. 1998a. The tobacco wounding-activated mitogen-activated protein kinase is encoded by SIPK. Proc. Natl. Acad. Sci. USA 95:7225-7230.

Zhang, S., and Klessig, D.F. 1998b. Resistance gene N-mediated de novo synthesis and activation of a tobacco mitogen-activated protein kinase by tobacco mosaic virus infection Proc. Natl. Acad. Sci. USA 95:7433-7438.

Zhang, S. and Klessig, D. F. 1999. Pathogen-induced MAP kinases in tobacco. Pages 65-84 in: MAP Kinase in Plant Signal Transduction, H. Hirt, ed. Springer-Verlag, Heidelberg, Germany.

Zhu, Q., and Lamb, C. 1991. Isolation and characterization of a rice gene encoding a basic chitinase. Mol. Gen. Genet. 226:289-296. 